\title{
Penerapan Problem Based Learning (PBL) Guna Meningkatkan Hasil Belajar Mata Pelajaran Matematika kelas X Semester Ganjil di SMK Negeri 2 Situbondo Tahun Pelajaran 2018/2019
}

\author{
Tri Astindari, Irma Noervadila \\ Pendidikan Matematika STKIP PGRI Situbondo \\ email: triaswiji01@gmail.com
}

\begin{abstract}
Abstrak
Tujuan dari penelitian ini adalah untuk mengetahui peningkatan hasil Belajar Siswa dengan menerapkan Problem Based Learning (PBL) Kelas X Mata Pelajaran Matematika di SMK Negeri 2 Situbondo Tahun Pelajaran 2018/2019. Pendekatan penelitian yang digunakan adalah pendekatan kualitatif sedangkan jenis penelitiannya adalah penelitian tindakan kelas dengan subjek penelitian adalah siswa kelas X Ak di SMK Negeri 2 Situbondo. Data yang diperoleh dikumpulkan dengan metode observasi, wawancara, dan dokumentasi, sedangkan pelaksanaannya dimulai pada tanggal 1 Agustus 2018 sampai dengan tanggal 5 September 2018. Berdasarkan hasil analisis dapat diketahui bahwa PBL dapat meningkatkan kemampuan akademik dan dapat meningkatkan kemampuan kerjasama antar siswa, karena dengan pembelajaran berbasis masalah siswa dapat menemukan sendiri konsep yang harus diketahui berdasarkan penyelidikan terhadap masalah nyata. Pada siklus I dicapai ketuntasan belajar klasikal sebesar $83 \%$ dan secara perorangan siswa yang tuntas sebanyak 25 siswa dan 5 siswa tidak tuntas. Faktor - faktor yang menyebabkan tidak tuntas belajar dari 5 siswa tersebut adalah mereka kurang menguasai materi, kurang teliti, malu bertanya, dan kurang pandai mengatur waktu dalam mengerjakannya. Pada siklus II dicapailah ketuntasan belajar siswa secara klasikal sebesar $89 \%$ sebanyak 27 siswa yang tuntas secara individu.
\end{abstract}

Kata Kunci : Problem Based Learning, Metode Pembelajaran, Hasil Belajar Siswa

\begin{abstract}
The purpose of this study was to determine the improvement in Student Learning outcomes by applying Problem Based Learning (PBL) Class X Mathematics Subjects at SMK Negeri 2 Situbondo 2018/2019 Academic Year. The research approach used is a qualitative approach while the type of research is classroom action research with the subject of research is the X Class students at SMK Negeri 2 Situbondo. The data obtained were collected by the method of observation, interviews, and documentation, while the implementation began on 1 August 2018, until 5 September 2018. Based on the results of the analysis it can be seen that PBL can improve academic ability and can improve the ability of collaboration between students because with learning problem-based students can find their own concepts that must be known based on an investigation of real problems. In the first cycle, classical learning completeness achieved by $83 \%$ and individually students who completed as many as 25 students and 5 students did not complete. Factors that caused incomplete learning from the 5 students were they did not master the material, were not thorough, were embarrassed to ask questions, and we're
\end{abstract}


not good at managing time to do it. In cycle II the classical learning completeness achieved by $89 \%$ as many as 27 students who completed individually.

Keywords: Problem Based Learning, Learning Methods, Student Learning Outcomes

\section{PENDAHULUAN}

Kualitas suatu bangsa sangat ditentukan oleh faktor pendidikan. Peran pendidikan sangat penting untuk menciptakan kehidupan yang cerdas, damai, terbuka dan demokratis. Oleh karena itu, pembaharuan pendidikan harus selalu dilakukan untuk meningkatkan kualitas pendidikan nasional. Dalam konteks pembaharuan pendidikan, ada tiga isu utama yang perlu disoroti, yaitu pembaharuan kurikulum, peningkatan kualitas pembelajaran dan efektivitas metode pembelajaran (Nurhadi dan senduk, 2003:1). Kurikulum pendidikan harus komprehensif dan responsive terhadap dinamika sosial, relevan, dan mampu mengakomodasi keberagaman keperluan dan kemajuan teknologi. Kualitas pembelajaran harus ditingkatkan untuk meningkatkan kualitas hasil pendidikan. Untuk meningkatkan kualitas pembelajaran dapat dilakukan dengan menggunakan strategi atau pendekatan pembelajaran yang efektif di kelas, serta lebih memberdayakan potensi siswa.

Kita telah melihat bagaimana keras siswa kami bekerja tetapi mereka masih memiliki kesulitan dalam memahami konsep yang diajarkan. Mereka bekerja pada banyak masalah untuk meningkatkan pemahaman mereka, Tetapi masih ditanyakan pertanyaan rutin yang sulit. Kami melihat bahwa siswa tersebut tidak dapat melihat umum melalui keterangan atau keterangan pada umunya ketika berhadapan pada konsep-konsep matematika. Mereka tidak dapat melihat fiturfitur penting dari teknik matematika ketika disajikan dalam bentuk yang berbeda(Roselainy et. Al., 2010). Kami beralasan bahwa ada metode yang lebih efektif untuk mendukung pembelajaran siswa. Jadi, Kami memutuskan untuk menerapkan PBL untuk meningkatkan kekuatan berfikir matematika pada siswa dalam memahami konsep dan permasalahan (Roselainy. A. R: 2012).

PBL bertujuan untuk mengembangkan kemampuan berfikir, pemecahan masalah, dan keterampilan intelektual. Pembelajaran berbasis masalah digunakan untuk merangsang berfikir tingkat tinggi dalam situasi berorientasi masalah, termasuk di dalamnya belajar bagaimana belajar. Masalah yang dikaji adalah masalah yang bersifat terbuka, yang memungkinkan banyak jawaban dari masalah yang sedang dikaji (Seituni, 2019). Masalah yang disajikan diusahakan yang berhubungan dengan dunia nyata.

Dalam pembelajaran berbasis masalah yang berperan aktif adalah murid, sedangkan guru hanya sebatas memberikan bimbingan. Guru menyajikan masalah kemudian memotivasi siswa agar aktif dalam proses pemecahan masalah tersebut. Secara teoritis pembelajaran berbasis masalah dapat memberikan harapan yang posistif bagi peningkatan hasil belajar matematika. 
PBL di anggap oleh banyak akhli pendidikan sebgaia unggul kuliah tradisional, terutama untuk belajar keterampilan tingkat tinggi dan konsep. PBL dapat lebih diperkuat melalui pemanfaatan keterampilan metakognitif pada siswa, karena penggunaan yang luas adalah penting untuk memastikan bahwa metode PBL dapat meningkatkan strategi metakognetif yang mendorong dialog jiwa batin. PBL berbeda dengan tradisional lainnya karena melibatkan proses pengaturan kontek dengan menggunakan masalah realistis, mengaktifkan belajar dengan teman sebaya, mengembangkan pengetahuan konsep yang relavan, menerapkan pengetahuan sebelumnya utnuk memecahkan masalah. PBL dalam pendekatan ini mengembangkan keterampilan pemecahan masalah dapat mendorong kesdaaran siswa tentang proses berfikir mereka sendiri. Hal ini dapat dicapai dengan melengkapin siswa dengan pertanyaan prosedural untuk mendorong selfawarness lebih besar (Angeli.M, 2016).

Fitur utama dari PBL adalah di kontekstualisasikan belajar melalui masalah diselesaikan dengan siswa kelompok tutorial tanpa kuliah formal atau persiapan sebelumnya (Mubuuke.A.G, 2016).

Kombinasi tindakan dan penelitian (action and reaserch) telah memberikan kontribusi terhadap daya tarik bagi para peneliti, guru dan masyarakat akademik dan pendidikan pada umumnya. Peneliti tindakan sebagai suatu metode sangat mengesankan hampir kondisi apapun dimana masalah yang melibatkan orang, tugas dan prosedur guna mencari solusi, atau dimana beberapa perubahan bentuk menghasilkan sesuatu yang diharapkan. Konsepsi berbeda dari (action and reaserch)menunjukkan bahwa kombinasi dari tindakan yang membuat bentuk penyelidikan disiplin, diman upaya pribadi dibuat untuk memahami, memperbaiki dan mereformasikan praktik. Penelitian tindakan adalah partisipatif dilakukan melalui mana orang bekerja menuju perbaikan praktek mereka sendiri dan membnagun sikap kritis masayarakat atas orang yang berpartisipasi dan berkolaborasi dalam tahap proses penelitian. Tujuan penelitian tindakan membangun komunitas orang - orang yang berkomitmen untuk mencerahkan diri tentang hubungan antara keadaan, tindakan dan konsekuensi dalam situasi mereka sendiri, dan membebaskan diri dari kendala kelembagaan dan pribadi membatasi kekuasaan untuk menghidupkan ni;lai pendidikan yang dialami dan nilai sosial yang ada.

Penelitian tindakan tindakan memungkinkan kita untuk memberikan pembenaran beralasan kerja pendidikan kepada orang lain, karena menunjukkan bagaiman bukti yang sudah dikumpulkan dan direfleksi kritis yang telah dilakukan dan membantu membuat alasan yang dikembangkan (Tatang .A, 2016).

Hal ini didukung oleh hasil penelitian Suwarno bahwa pembelajaran berbasis masalah dapat meningkatkan hasil belajar (Suwarno, 2003). Tetapi hal ini masih perlu dikembangkan. Penelitian model pembelajaran berbasis masalah ini 
bertujuan untuk mengembangkan penelitian yang telah dilakukan. Dari latar belakang masalah di atas, maka peneliti tertarik untuk mengadakan penelitian dengan judul "Penerapan Problem Based Learning (PBL) guna meningkatkan hasil belajar mata pelajaran Matematika kelas X Semester Ganjil di SMK Negeri 2 Situbondo Tahun Pelajaran 2016/2017

\section{METODE PENELITIAN}

Lokasi penelitian merupakan wilayah dimana diadakan suatu penelitian. Dalam penentuan daerah penelitian ini tidak ada ketentuan seberapa luas yang harus dimulai untuk ditetapkan sebagai lokasi penelitian. Lokasi Penelitian yang dipilih yaitu SMK Negeri 2 Situbondo.

Jenis penelitian ini adalah penelitian tindakan kelas. Menurut Hobri (2007) Penelitian tindakan kelas merupakan bagian dari penelitian tindakan secara umum yang memiliki beberapa pengertian yaitu :

1. Penelitian yang dilakukan di kelas ;

2. Penelitian tindakan yang menyangkut masalah-masalah kelas (interaksi siswa dan guru) ;

3. Penelitian tindakan kelas yang menyangkut masalah pendidikan dan pembelajaran.

Model skema yang digunakan dalam penelitian ini adalah model Hopkins yaitu model skema yang menggunakan prosedur kerja yang dipandang sebagai siklus spiral. Siklus ini terdiri dari 4 tahap yaitu perencanaan, tindakan, observasi dan refleksi yang kemudian diikuti siklus spiral berikutnya. Berdasarkan model skema penelitian tindakan Hopkins maka dikembangkan desain penelitian yang tersaji

pada

gambar

1. 


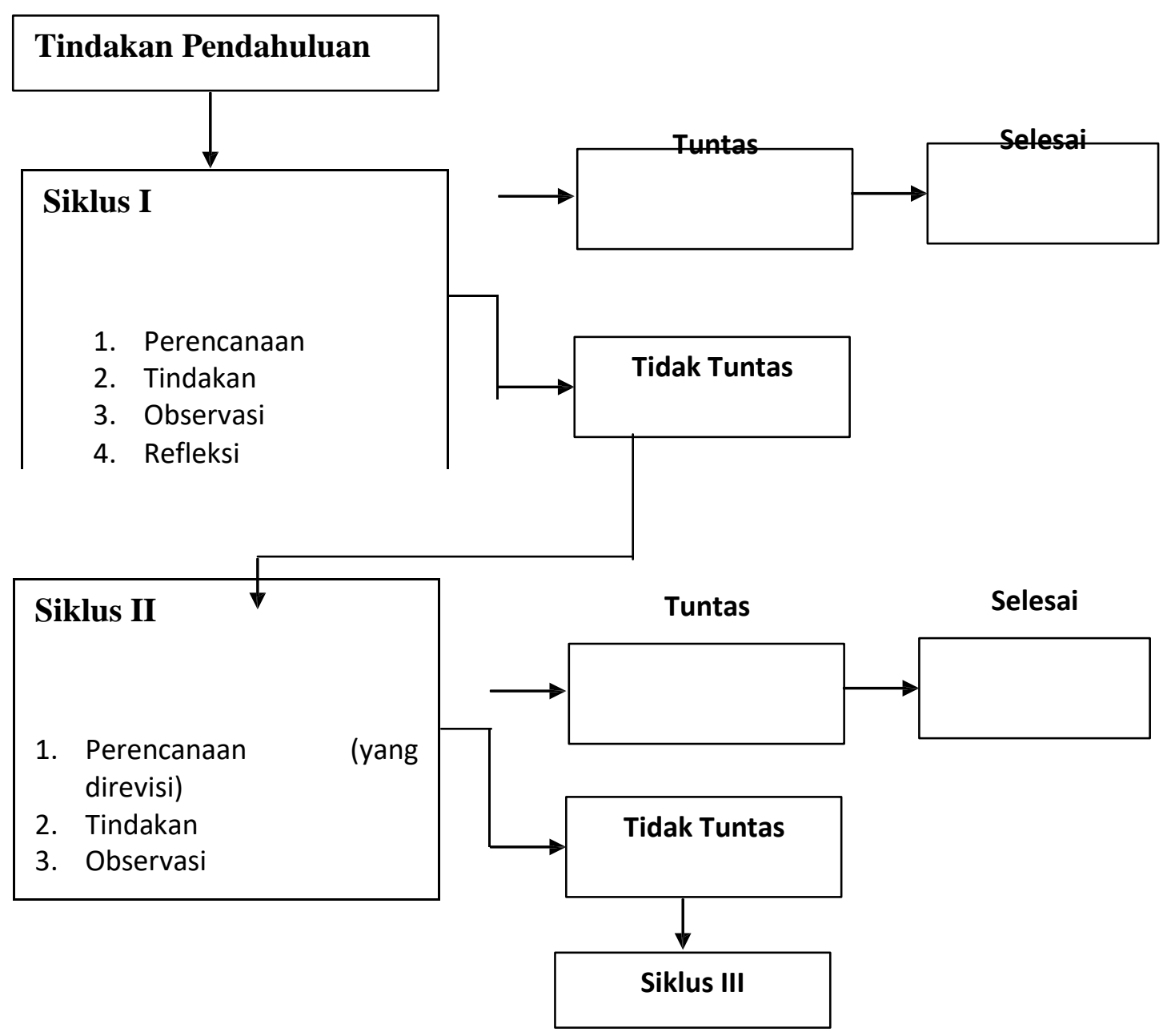

Berdasarkan desain penelitian di atas, maka direncanakan bahwa penelitian ini terdiri dari dua siklus. Siklus I dan II dilaksanakan terhadap seluruh siswa kelas X Ak.1 SMK Negeri 2 Situbondo, Tetapi jika pada siklus I masih terdapat siswa yang tidak tuntas secara individual maka dilanjutkan dengan siklus II.

\section{Rincian / Prosedur Penelitian}

\section{Perencanaan}

Dalam tahap ini peneliti menyiapkan instrumen penelitian secara rinci yang meliputi :

1) Menyusun rencana pembelajaran

2) Menyusun lembar kerja siswa berdasarkan implementasi model pembelajaran berbasis masalah.

3) Menyusun soal tes sebanyak 5 soal berbentuk subyektif beserta kunci jawaban dan pedoman penskoran

4) Menyusun pedoman pengamatan dan interview. 


\section{Tindakan dan Observasi}

a. Tindakan

1) Kegiatan Pembelajaran

Pembelajaran sub pokok bahasan permutasi dan kombinasi dengan menggunakan pembelajaran berbasis masalah dilaksanakan sesuai dengan rencana pembelajaran dan lembar kerja siswa yang telah tersusun.

2) Pelaksanaan tes

Pada akhir kegiatan pembelajaran sub pokok bahasan permutasi dan kombinasi dilaksanakan tes individual untuk mengukur hasil belajar siswa. Soal tes yang digunakan adalah subyektif tentang materi permutasi dan kombinasi

b. Observasi

1. Kegiatan observasi dilakukan bersama - sama dengan pelaksanaan tindakan

2. Dalam penelitian ini yang diobservasi adalah pelaksanaan pembelajaran yang meliputi aktivitas guru (peneliti) dan siswa.

3. Tujuan dilaksanakannya observasi ini adalah untuk mengetahui apakah guru telah mengajar sesuai dengan model pembelajaran berbasis masalah atau tidak

4. Lembar observasi dibuat berdasarkan aktivitas guru dan siswa

5. Observer adalah guru mata pelajaran matematika yang sebelumnya peneliti penyampaikan akan menggunakan metode pembelajaran berbasis masalah dalam proses pembelajaran materi pokok sistem pernafasan manusia.

c. Analisis hasil tes dan observasi

1) Untuk mengukur hasil belajar siswa dilakukan analisis kuantitatif dengan rumus kriteria ketuntasan belajar siswa.

2) Hasil observasi berupa data kualitatif tentang aktivitas guru dan siswa selama kegiatan berlangsung. Data tersebut dianalisis secara deskriptif.

d. Wawancara / Interview

1) Wawancara dilakukan terhadap siswa kelas $X$ Ak.1 SMK Negeri 2 Situbondo baik yang tuntas maupun yang tidak tuntas. Tujuan dilakukannya wawancara adalah untuk mengetahui tanggapan siswa tentang pembelajaran matematika menggunakan model yang telah ditetapkan dan untuk mengetahui kesulitan-kesulitan siswa selama proses pembelajaran berlangsung.

2) Analisis Hasil Wawancara

Hasil wawancara berupa data kualitatif dan dianalisis secara deskriptif

\section{Refleksi}

Refleksi merupakan upaya untuk mengkaji suatu tindakan yang telah ditetapkan. Hasil analisis tes dan hasil obeservasi yang telah dilakukan, dijadikan 
dasar untuk melakukan tindakan selanjutnya, yaitu apakah perlu dilakukan siklus II atau cukup sampai di sini.

\section{Pengumpulan Data}

\section{Observasi}

Observasi adalah suatu teknik penelitian yang dilakukan dengan cara mengadakan pengamatan terhadap suatu obyek baik secara langsung maupun tidak langsung (Ali, 2000:72). Sedangkan menurut Hobri (2007:17) Observasi dilakukan untuk mengamati kegiatan di kelas selama kegiatan pembelajaran. Kegiatan yang diamati meliputi aktivitas pengajar dan aktivitas siswa dalam pembelajaran.

\section{Wawancara}

Sedangkan menurut Hobri (2007:17) Wawancara dilakukan untuk menelusuri dan mengetahui pemahaman siswa tentang materi tertentu dan cara menunjukkan kebenaran. Selain itu, wawancara dilakukan untuk mengetahui respon siswa dalam bekerjasama dan respon siswa terhadap pembelajaran. Dalam wawancara selalu ada dua pihak yang masing-masing mempunyai kedudukan yang berbeda, yaitu sebagai pengejar informasi dan sebagai pemberi informasi.

\section{Tes}

Tes adalah pertanyaan atau latihan yang diberikan untuk mengetahui dan mengukur pengetahuan, keterampilan, intelegensi, bakat dan kemampuan siswa dalam memahami dan menguasai materi. Dalam penelitian ini jenis tes yang digunakan adalah tes tertulis bentuk uraian (essay), karena tes dalam bentuk ini dapat memunculkan kreativitas siswa dalam berpikir dan menyusun jawaban sesuai dengan pendapat dan pemikiran mereka sendiri.

\section{Dokumentasi}

Metode dokumentasi adalah suatu pengumpulan data yang diperoleh dari catatan transkip atau dokumen-dokumen yang memang sudah ada. Sedangkan Husaini Usman mengatakan bahwa tehnik pengumpulan data dengan dokumentasi ialah pengambilan data yang diperoleh melalui dokumen-dokumen (2001:73).

\section{Analisa Data}

Analisis data adalah merupakan cara yang paling menentukan untuk menyusun data yang terkumpul, sehingga dapat menghasilkan suatu kesimpulan yang dapat dipertanggungjawabkan kebenarannya. Analisis data yang digunakan pada penelitian ini adalah data kualitatif. Data kualitatif digunakan untuk menentukan ketuntasan siswa dalam pembelajaran dengan Problem Based Learning pada pembelajaran dan kegiatan guru (peneliti) selama proses pembelajaran berlangsung. Analisis data kualitatif adalah analisis data yang diperoleh diperoleh dari hasil tes dan obaservasi. Pada penelitian ini analisis data kualitatif digunakan untuk menentukan ketuntasan belajar siswa dan keaktifan siswa dalam pembelajaran dangan strategi Problem Based Learning. Rafi'i 
(2002: 23) menyatakan bahwa rumus yang digunakan dalam menganalisis ketuntasan belajar adalah :

$$
\mathrm{P}=\frac{\mathrm{n}}{\mathrm{N}} \times 100 \%
$$

Keterangan :

$\mathrm{P}=$ Persentase ketuntasan belajar siswa

$\mathrm{n}=$ Jumlah siswa yang mencapai skor tes $\geq 70$ dari skor maksimal 100

$\mathrm{N}=$ jumlah siswa keseluruhan

Kriteria ketutasan belajar siswa dapat dinyatakan sebagai berikut :

a. Daya serap perorangan yaitu seorang siswa dikatakan tuntas belajar apabila telah mencapai skor $\geq 70$ dari skor tes maksimal 100 .

b. Daya serap klasikal yaitu suatu kelas dikatakan tuntas belajar apabila minimal $\quad 80 \%$ siswa yang tuntas dengan nilai $\geq 70$

\section{Hasil dan Pembahasan}

Hasil Pertemuan I

\begin{tabular}{|c|c|c|c|c|}
\hline \multirow{2}{*}{ Nilai } & \multicolumn{2}{|c|}{ Pra Siklus } & \multicolumn{2}{c|}{ Siklus I } \\
\cline { 2 - 5 } & Jumlah siswa & Persentase & Jumlah siswa & Persentase \\
\hline$\geq 70$ & 24 & $73 \%$ & 26 & $83 \%$ \\
$<70$ & 8 & $27 \%$ & 6 & $17 \%$ \\
\hline Jumlah & $\mathbf{3 2}$ & $\mathbf{1 0 0} \%$ & $\mathbf{3 2}$ & $\mathbf{1 0 0 \%}$ \\
\hline
\end{tabular}

\section{Hasil Pertemuan II}

\begin{tabular}{|c|c|c|c|c|}
\hline & Jumlah siswa & Persentase & Jumlah siswa & Persentase \\
\hline Nilai & \multicolumn{3}{|c|}{ Siklus I } & \multicolumn{2}{c|}{ Siklus II } \\
\hline$\geq 70$ & 25 & $83 \%$ & 27 & $89 \%$ \\
$<70$ & 5 & $17 \%$ & 3 & $11 \%$ \\
\hline Jumlah & $\mathbf{3 0}$ & $\mathbf{1 0 0} \%$ & $\mathbf{3 0}$ & $\mathbf{1 0 0 \%}$ \\
\hline
\end{tabular}

\section{PEMBAHASAN}

Hasil yang diperoleh dalam penelitian ini menunjukkan adanya peningkatan hasil belajar siswa antara sebelum tindakan dan sesudah tindakan penelitian. Sebelum tindakan diperoleh hasil belajar siswa secara klasikal sebesar $77 \%$, setelah pembelajaran siklus I dilaksanakan maka terjadi peningkatan hasil belajar sebesar $6 \%$. Ketuntasan klasikal yang diperoleh pada siklus I sebesar 83\%. Hasil ketuntasan belajar pada siklus I masih belum mencapai kriteria ketuntasan yang sudah ditentukan dan dilanjutkan pada pelaksanaan pembelajaran siklus II. Setelah pelaksanaan pembelajaran di siklus II terjadi peningkatan hasil belajar sebesar 5,57 \% dibanding pembelajaran siklus I. Ketuntasan belajar secara klasikal pada siklus II sebesar 88,57 \%, dengan hasil belajar yang diperoleh pada siklus II dapat dikatakan bahwa siswa kelas X Ak.1 SMK Negeri 2 Situbondo 
pada pembelajaran matematika dengan kompetensi dasar sistem persamaan linier terjadi peningkatan dan mencapai ketuntasan klasikal.

\section{KESIMPULAN}

Berdasarkan hasil penelitian dan analisa pembelajaran, dapat disimpulkan bahwa melalui penerapan Problem Based Learning (PBL) hasil belajar siswa mata pelajaran matematika kompetensi dasar dasar sistem persamaan linier siswa kelas X Ak.1 semester ganjil tahun pelajaran 2016/2017 di SMK Negeri 2 Situbondo meningkat dan mencapai ketuntasan klasikal, karena hasil belajar siswa sudah dapat memenuhi standar ketuntasan belajar $\geq 85 \%$ yang ditelah ditetapkan dalam penelitian ini.

\section{DAFTAR PUSTAKA}

2006. Contoh / Model Silabus Mapel IPS SMP. Jakarta; Depdiknas.

Aloysius Gonzaga Mubuuke. 2016. Faktor Faktor kognitif dan sosial mempengaruhi respon siswa dan pemanfaatan fasilitator masukan dalam pembelajaran PBL. Afrika Selatan: Universitas Stellenbosch.

Arikunto, S. 2000. Dasar - Dasar Evaluasi Pendidikan. Jakarta; Bumi Aksara.

Arikunto, S. 2006. Prosedur Penelitian Suatu Pendekatan Praktik. Jakarta; Rineka Cipta.

Cooper et, Al. 1999. Classroom Teacing Skill, Edisi 9. Virginia; Univ. of Virginia.

Dimyati dan Mulyono. 2002. Belajar dan Pembelajaran. Jakarta; Rineka Cipta.

Djamarah, Saiful Bahri \& Aswan Zaini. 1999. Strategi Belajar Mengajar. Jakarta; Reneka Cipta.

Djamarah, Saiful Bahri. 2002. Strategi Belajar Mengajar. Jakarta; Rineka Cipta.

Hakim, T. 2001. Belajar Secara Efektif. Jakarta; Puspa Swara.

Ibrahim, Muslim dkk. 2004. Pembelajaran Kontekstual ( Contexstual Teaching and Learning / CTL ) dan Penerapan dalam KBK. Malang; Univ. Negeri Malang.

Lei, A. 2005. Mempraktekkan Cooperative Learning di Ruang - ruang Kelas. Jakarta; Grasindo.

Michael Angelo B. 2016. Problem Based Learning of Process system Engineering and Process Integartion Concept with Metacognitive Strategies. Filipina ; Universitas Manila

Nur. 2001. Pembelajaran Kooperatif. Surabaya.

Nurhadi dan Senduk. 2003. Pembelajaran Kontekstual dan Penerapannya dalam KBK. Malang; Universitas Negeri Malang.

Roselainy abdul rahman. 2012. Meningkatkan Pengajaran Teknik matematika menggunakan penelitian tindakan. Malaysia ; UTM Kuala Lumpur

Seituni, S. (2019). Analisis Model Pembelajaran Problem Based Learning Dalam Upaya Peningkatan Aktivitas Mahasiswa Terhadap Sikap Demokratis Pada 
EDUSAINTEK: Jurnal Pendidikan Sains dan Teknologi $\quad$ VOLUME 6. No. 2 November $2019 \quad$ ISSN: 1858-005X

Mata Kuliah Pendidikan Kewarganegaraan. Jurnal Bimbingan dan

Konseling Terapan, 3(1), 95-104.

Sudjana. 2002. Belajar dan Pembelajaran. Bandung. 
Sugiyono, Prof. Dr. 2005. Memahami Penelitian Kualitatif. Bandung; Alfabeta. Sukidin, Basrowi \& Suranto. 2002. Manajemen Penelitian Tindakan Kelas. Jakarta; Insan Cendekia.

Surakhmad, Winarto. 2003. Pengantar Interaksi Belajar Mengajar : Dasar dan Tehnik Metodelogi Pengajaran. Bandung; Tarsito.

Tatang Ary G. 2016. Metode Penelitian Pendidikan. Jakarta; Mitra Wacana Media.

Winataputra. 2001. Model - Model Pembelajaran Inovatif. Jakarta; Universitas Terbuka. 